\title{
A CASE OF CEREBRAL SPARganOSIS IN SOUTH AMERICA
}

ALEJANDRO M. E. BOERO * - PEDRO GARAGUSO ** - JORGE NAVARRÉ ***

\begin{abstract}
SUMMARY - Cerebral sparganosis (CS) is a parasitic infection caused by the larva of Spirometry mansonoides. Rarely it can affect the human brain. We report the case of a 24-year old man from Paraguay who suffered from seizures and headache for one. year. A frontal tumor was diagnosed by CT-scan and was subsequently resected. The pathological examination revealed a larva with Sparganum characteristics. The evolution of the patient was satisfactory. As far as we know, this is the first case of CS reported in South-America.
\end{abstract}

Um caso de esparganose cerebral na América do Sul.

RESUMO - Esparganose cerebral (EC) é infecção parasitária causada pela larva do Spiro-ᄀ metra mansonoides. Raramente afeta o cérebro humano. Descrevemos o caso de um paciente paraguaio com 24 anos, que apresentava convulsões freqüentes e cefaléia há um ano. Tumor frontal foi diagnosticado por TC de crânio e ressecado posteriormente. O exame anatomopatológico evidenciou larva com características de Sparganum. A evolução do paciente foi satisfatória. Que seja de nosso conhecimento, este é o primeiro caso de EC relatado na América do Sul.

Cerebral sparganosis (CS) is a rare infection caused by larva of genera «Spirometra» or «Diphyllobotrium». The disease has been sporadically observed in Asia and in oriental and european immigrants living in the USAi-fi.s.S.

To our knowledge, CS has never been reported in South America befoTe.

\section{CASE REPORT}

LR, a 24 year-old southamerican male was admitted to the Ramos Mejia Hospital because of seizures. He had been healthy untill one year before, when he developed headaches and frequent episodes of deviation of gaze followed by generalized seizures. The interictal BEG was normal. He was started on phenytoin ( $300 \mathrm{mg} / \mathrm{day})$ without benefit. $\mathrm{He}$ was born in Paraguay and had always lived in rural areas, in permanent contact with domestic animals. He had never travelled abroad. His family history was non-contributory. General clinical examination was normal and the neurological examination showed mild weakness of left leg with left extensor plantar response. Routine laboratory exam was normal. A CT-scan of the head (Fig. 1) revealed a rigth frontal cortico-subcortical mass, which enhanced with contrast, surrounded by edema but without mass effect. An angiogram showed that the lesion was not vascularized. CSF examination was normal. The patient underwent a right frontal craniotomy, which revealed a gray yellowish tumoral mass that was resected. After surgery, he had complete recovery of his crural paresis and was discnarged free of seizures.

From the Divisions of Neurology, Parasitology and Neurosurgery, Ramos Mejía Hospital, Buenos Aires: * Chief of Residence, Division of Neurology; ** Professor of Parasito$\operatorname{logy} ; * * *$ Staff Neurosurgeon.

Dr. Alejandro M. E. Boero - División Neurología, Hospital General de Agudos J. M. Ramos Mejía - Urquiza 609 - 1221 Buenos Aires - Argentina. 


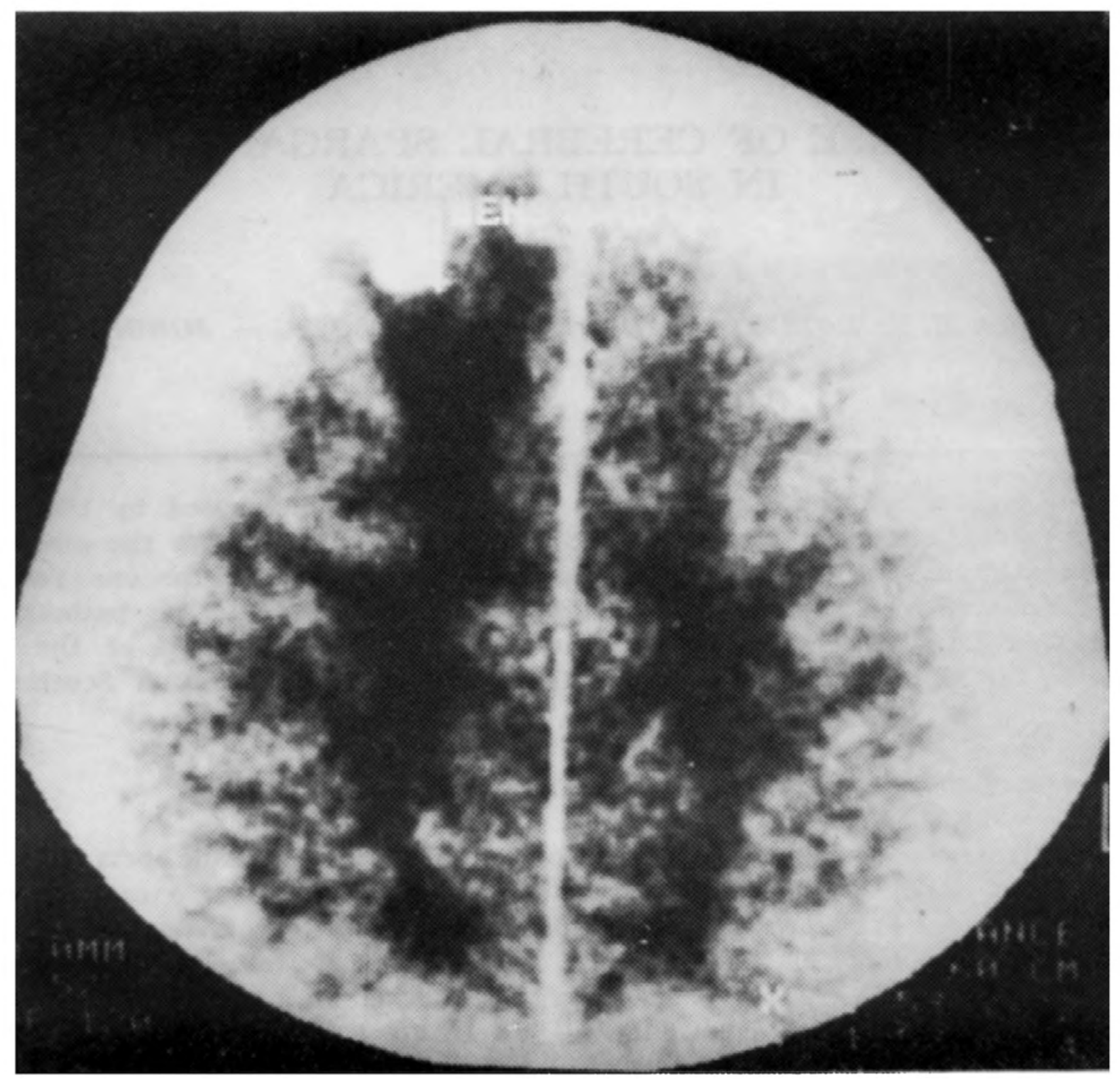

Fig. 1 - CT-scan with contrast enhancement showing a well circunscribed enhancing mass in the right frontal lobe.

Pathological findings - The surgical block was cut in 300 sections and stained with HE, PAS, Van Gieson and blue Gomori trichromic methods. The microscopic examination revealed areas of moderate gliosis with perivascular infiltrates of lymphocytes, plasma cells and eosinophils. In the center of these areas there was a small, solid and ribbonlike larva (Fig. 2A). The parasite was composed by a cuticular layer ridged at regular intervals, longitudinal and transversal muscular fibers and a longitudinal excretory duct (Fig. 2B). The head of the worm was amorphous, spherical, without hooks and cupping glasses. No celomic cavity could be observed. These histopatological findings are diagnostic for C'S J-e,*,s.

\section{COMMENTS}

Takeuchi reported the first case of CS in a young woman in $1918^{4}$. Since then, a few cases have been reported in the literature 1-6.8,9. Spirometra mansonoides and Diphyllobotrium latum are pseudophyllidean cestodes that develop their life cycle by harboring little crustaceae of the Cyclops genera. Some animals such as reptiles and amphibia serve as intermediary hosts, and several types of mammals as definitive hosts 7. Sparganosis can infect man by (1) drinking water contaminated with cyclops harboring procercoid larvae, (2) eating infected animal meat or (3) propagation by contiguity in ocular forms (poultice of contaminated frog flesh)3,io. CT scan findings usually correspond to cerebral lobar enhanced lesions 1-3,5 with perilesional edema mimicking a glioma. The clinical findings, CT images and good response to surgical treatment in our patient are similar to the cases reported previously i-6 $>^{8}$.

We would like to stress the importance of this pathology in South America, since it can be overlooked easily when clinics presents as an expanded lesion mimicking a brain tumor.

Acknowledgements - We thank Drs. H.A- Molina, J.D. Corréale, L,A.L. Resende and R.E.P. Sica for reviewing the manuscript. 

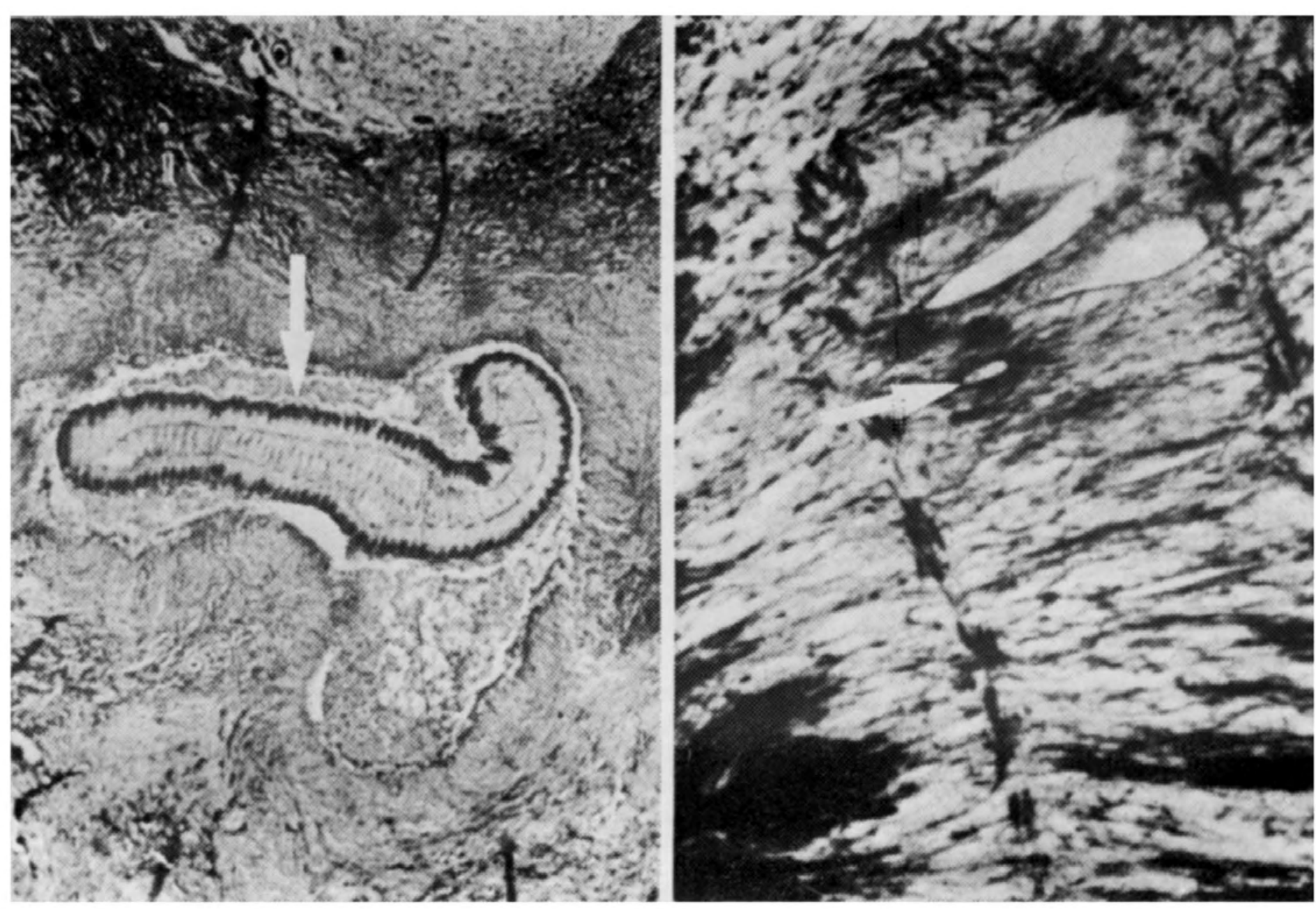

Fig. 2 - Tissue section of the cerebral block. A (left) - Panoramic view of the sparganum (arrow) in the middle of inflammatory cell infiltration land fibrogliotic reaction tissue.

$B$ (right) - Greater magnification of $2 A$ showing the cuticular layer ridged at the periphery, the longitudinal and transverse muscular fibers, and the excretory duct (arrow) (Blue Gomori trichrome, $\times 25$ and $\times 400)$.

\section{REFEREN CES}

1. Anders K, Foley K, Stern WE, Brown WJ. Intracranial sparganosis, an uncommon infection: case report. J Neurosurg 1984, 60:1282.

2. Chan S, Tse C, Chan Y, Fong D. Sparganosis of the brain. J Neurosurg 1987, $67: 981$.

3. Fan K, Pezeshkeour G. Cerebral sparganosis. Neurology 1986, 36:1249.

4. Kuroiwa T. Plerocercoid in human brain. Fukuoda Acta Med 1951, 43:275.

5. Mineura K, Mori T. Sparganosis of the brain: case report. J Neurosurg 1980, 52:588.

6. Monolo L, Pontiggia M, Tarfani A, Doriggi A. Su di un caso di sparganosi cerebrale. Riv Neurobiol 1976, $22: 69$.

7. Mueller J. The biology of spirometra. J Parasitol 1974, 60:3.

8. Nakajima H, Mitsui T, Suzuki M. Cerebral sparganosis: case report. Neurol Med Chir ( Tokyo) 1984, 24:427.

9. Pradatsundarasar A, Chihtanawongs C. Shuangshoti S. Sparganum-like parasite of the brain. Southeast Asian J (Trop Med Publ Health) 1971, 2:578.

10. Zhong H, Shao L, Lian D, Deng Z, Zhao S, Gao P, He L, Yun C, Pan J. Ocular sparganosis caused blindness. Chin Med J 1983, 96:73. 